\title{
The Relationship between Sperm Morphometry and Sperm Competition in Local Goats of Central Java, Indonesia
}

\author{
S. B. Wibowo ${ }^{\mathrm{a}}$, E. T. Setiatin ${ }^{\mathrm{b}}$, \& E. Kurnianto ${ }^{\mathrm{b}, *}$

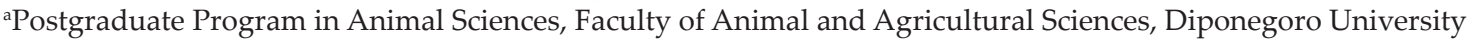 \\ ${ }^{b}$ Faculty of Animal and Agricultural Sciences, Diponegoro University \\ Tembalang Campus, Semarang 50275 - Indonesia \\ (Received 06-09-2013; Reviewed 25-10-2013; Accepted 12-11-2013)
}

\begin{abstract}
The objective of this study was to examine the relationship between sperm morphometry and sperm competition in local goats. Forty bucks were used in this study, consisted of 4 breeds namely Ettawa Grade Goat (EGG), Kejobong Goat (KJG), Kacang Goat (KCG), and Jawarandu Goat (JWG), each breeds consisted of 10 bucks. GLM, REG and DISRCRIM procedures of SAS were used to compute all data observed. UPGMA of MEGA 5 was used to illustrate the genetic distance among breeds. The result showed that there were differences in the sperm morphometry among 4 breeds of goats $(P<0.05)$. Sperm length positively related to the level of sperm competition in all local goats $(P<0.05)$ although the value of coefficient of determinant was low $\left(r^{2}=0.0043\right)$. Within breed analysis showed that there was no positive relationship between sperm length and level of sperm competition in EGG and JWG goats. Midpiece area positively related to the principal piece $(P<0.05)$. Sperm morphometry had a significant positive relation to sperm competition in local goats of Central Java.
\end{abstract}

Key words: local goats, sperm competition, sperm morphometry

\section{ABSTRAK}

Penelitian ini bertujuan untuk mengkaji hubungan antara morfometri spermatozoa dengan kompetisi spermatozoa pada kambing lokal. Empat puluh pejantan kambing digunakan dalam penelitian ini yang terdiri atas 4 bangsa, yaitu: Peranakan Ettawa (PE), Kejobong (KJ), Kacang (KC) dan Jawarandu (JR), masing-masing bangsa terdiri atas 10 ekor. Analisis data dilakukan menggunakan SAS melalui prosedur GLM, REG dan DISCRIM. UPGMA dari MEGA 5 digunakan untuk menggambarkan jarak antar bangsa. Hasil penelitian menunjukkan bahwa terdapat perbedaan morfometri spermatozoa diantara 4 bangsa kambing $(P<0,05)$. Panjang spermatozoa berhubungan positif dengan level kompetisi spermatozoa pada seluruh bangsa kambing $(\mathrm{P}<0,05)$ meskipun koefisien determinan rendah $\left(r^{2}=0,0043\right)$. Analisis dalam bangsa menunjukkan bahwa tidak terdapat hubungan positif antara panjang sperma dengan level kompetisi sperma pada PE dan JR. Luas area midpiece berhubungan positif dengan principle piece $(\mathrm{P}<0,05)$. Morfometri spermatozoa berhubungan dengan kompetisi spermatozoa pada kambing lokal Jawa Tengah.

Kata kunci: kambing lokal, kompetisi spermatozoa, morfometri spermatozoa

\section{INTRODUCTION}

Sperm competition that was identified in 1970, is an event where two or more males mate with a female in any given receptive period. Sperm from each ejaculate compete to fertilize ovum (Parker \& Pizzari, 2010). The study about sperm competition have been reported

*Corresponding author:

E-mail: kurniantoedy17@gmail.com in mammals (Tourmente et al., 2011), amphibia (frog) (Byrne et al., 2003), and red deer (Malo et al., 2005).

Sperm morphometry is defined as a measure of the sperm dimensions (head area, midpiece area, principal piece length, flagella length and sperm length $(\mu \mathrm{m}))$. An automated sperm morphometry analysis system (ASMA) is a method that used for sperm morphometry analysis (Marco-Jiménez et al., 2006). The experimental study of Hosken \& Ward (2001) showed that there was positive relation between level of sperm competition and relative testis mass. Increasing in testis mass will increase in the amount of sperm-producing tissue, so it can be assumed 
that large testis will produce more sperm in ejaculate (Lüpold et al., 2009). Therefore, testis mass was often used as measure of the level sperm competition.

There are two component of sperm relating to sperm competition is still debated in evolutionary biology. Firstly, increasing of midpiece will generate in greater energy due to increasing mitochondrial area (Gomendio \& Roldan, 2008). Secondly, increasing of flagella length is expected to increase swimming velocity, therefore it can be assumed there will be increasing in motility percentage. The both of components were important due to the need of velocity to arrive early in the site of fertilization within female reproductive tract.

Longer flagella will increase in sperm swimming velocity. In other hand, sperm energy is produced by mitochondrial within midpiece area. Greater energy is needed for sperm velocity. Positive correlation between longer flagella and midpiece area may give a good impact on sperm longevity. Firman \& Simmons (2010) stated that size of midpiece is a predictor of swimming velocity of Mus musculus domesticus sperm. Different results shown by Malo et al. (2006) who found a negative relationship between midpiece length and swimming velocity in red deer (cervus elaphus).

The evidence of a positive relationship between sperm size and testis mass (proxy sperm competition) has been supported by several studies on various taxa (Tourmente et al., 2011). Inter-specific studies suggest that sperm competition was positively relating with greater number of sperm. The larger testes produce more sperm. Increasing on sperm size increasing in the sperm competition, however different results shown by Immler \& Birkhead (2007) who found inconsistent results on passerine birds. The results indicated that there was positive relationship among midpiece and flagella length to sperm competition in Fringillidae, therefore a positive relationship between sperm size and sperm competition was found in Sylviidae.

Sperm competition is a controversial issue during in the last $20 \mathrm{yr}$ and unresolved in mammals. However, the results were still doubt. Several studies indicate inconsistent results and tend to vary among researchers. The study on sperm competition in Indonesian local goats is still rarely reported.

The objective of this study was to examine the relationship between sperm morphometry and sperm competition in local goats of Indonesia. In addition, to examine the relationship between midpiece area and principal piece length closely relating to the sperm velocity and viability.

\section{MATERIALS AND METHODS}

\section{Materials}

Semen of forty bucks (n) were used as materials in this study, consisted of 4 breeds, namely Ettawa Grade Goat (EGG), Kejobong Goat (KJG), Kacang Goat (KCG), and Jawarandu Goat (JWG), in which each breeds consisted of 10 buck. Data were taken from sperm morphometry, testis mass and body mass.

\section{Methods}

Testis and body mass measurements. Semen was collected using an artificial vagina (AV). Data of testis mass were obtained by measuring testicular volume (liters) from live buck. Volume measurements were measured by dipping testicles into a measuring cup scale containing water, then water wasted was assumed as a measure testicular volume measured. Testicular volume measurements were based on the archimedes principle, in which the volume of the object that placed in water, equal to the volume of the water displaced (Sears \& Zemansky, 1994). Testis mass measurements based on formula $\mathrm{m}=\mathrm{Q} \mathrm{x} \mathrm{v}$, where $\mathrm{Q}$ testis $=1.40 \mathrm{~g} / \mathrm{cm}^{3}$ (ICRU Report 44, 1989). Body mass data was obtained by weighing the goats body weight $(\mathrm{kg})$.

Sperm morhometry measurements. Semen was collected by artificial vagina and then dissolved in $0.9 \%$ physiological saline (1:6) on the object glass and air dried. The object glass were fixed by Bunsen flame and after that washed in alcohol absolute (cat. no. 100983 by MERCK) for 4 minutes then air dried. Put inside Cloramin 0.5\% for $2 \mathrm{~min}$. After that the object glass were washed with distilled water, then placed in 95\% alcohol, then stained with Williams solution for 8-10 min. The object glass were washed in running water and dried (Arifiantini et al., 2006). The sperm were photographed using a Nikon phase-contrast microscope with a magnification of 400 times.

Sperm morphometry measurements were made using "ImageJ software" to 80 sperm cells in each buck. It was about 3200 sperm cell were observed. Micrometer was used to determine the unit of measurement. Flagella length was measured using "Segmented Line". Head area and midpiece measurements were using "Threshold" to make adjustments the image. After that, the part of sperm tail that are not measured may removed (F and G in Figure 1). "Fill holes" was used to enhance sperm head shape. "Filters" was used to refine the part to be measured.

\section{Statistical Analysis}

General Linear Model (GLM) procedure (SAS, 2004) was used to analyze multivariate and univariate analysis. REG procedure (SAS, 2004) was used to perform multiple regression analysis to investigate the relationship between sperm morphometry and relative testis mass. UPGMA (Unweighted Pair-Group Method with Arithmetic Mean) of MEGA 5 (Tamura et al., 2011) was used to perform distance among goat breeds based on sperm morphometry.

\section{RESULTS AND DISCUSSION}

\section{Sperm Morphometry}

Sperm morphometry data were taken from 3200 sperm cells with the distribution of 800 cells in each breeds of local goats. The result of measurements of sperm is presented in Table 1. 


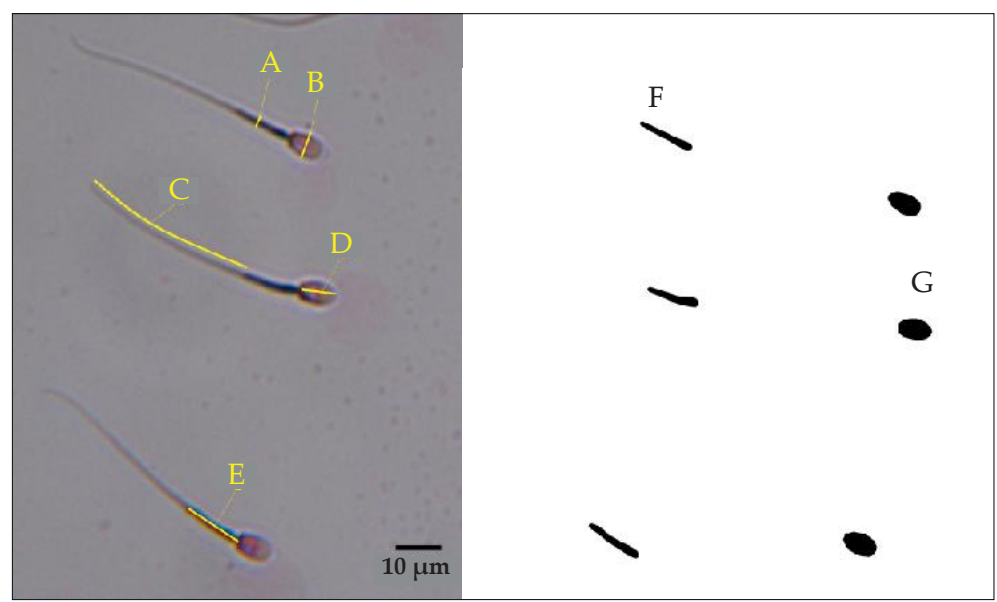

Figure 1. Sperm morphometry of Jawarandu goat, (A) midpiece width, (B) head width, (C) principal piece length, (D) head length, (E) midpiece length, (F) midpiece area, $(\mathrm{G})$ head area (phase contrast microscope, stained with Williams solution).

Table 1. Comparison of goats sperm morphometry

\begin{tabular}{lrrrr}
\hline \multirow{2}{*}{ Sperm morphometry } & \multicolumn{3}{c}{ Breed } \\
\cline { 2 - 5 } & \multicolumn{1}{c}{ EGG } & \multicolumn{1}{c}{ KJG } & JWG & KCG \\
\hline Head area $(\mu \mathrm{m})$ & $37.27 \pm 3.72^{\mathrm{c}}$ & $34.93 \pm 3.56^{\mathrm{d}}$ & $41.42 \pm 4.27^{\mathrm{a}}$ & $37.69 \pm 3.91^{\mathrm{b}}$ \\
Head length $(\mu \mathrm{m})$ & $9.50 \pm 0.52^{\mathrm{c}}$ & $9.30 \pm 0.56^{\mathrm{d}}$ & $9.95 \pm 0.55^{\mathrm{a}}$ & $9.65 \pm 0.53^{\mathrm{b}}$ \\
Head width $(\mu \mathrm{m})$ & $5.07 \pm 0.36^{\mathrm{b}}$ & $4.85 \pm 0.33^{\mathrm{c}}$ & $5.36 \pm 0.38^{\mathrm{a}}$ & $5.05 \pm 0.36^{\mathrm{b}}$ \\
Midpiece area $(\mu \mathrm{m})$ & $16.95 \pm 2.23^{\mathrm{b}}$ & $16.43 \pm 2.55^{\mathrm{c}}$ & $17.46 \pm 2.72^{\mathrm{a}}$ & $16.71 \pm 2.44^{\mathrm{b}}$ \\
Midpiece length $(\mu \mathrm{m})$ & $12.66 \pm 0.91^{\mathrm{b}}$ & $12.86 \pm 1.18^{\mathrm{a}}$ & $12.85 \pm 1.12^{\mathrm{a}}$ & $12.83 \pm 1.20^{\mathrm{a}}$ \\
Midpiece width $(\mu \mathrm{m})$ & $2.07 \pm 0.44^{\mathrm{c}}$ & $2.00 \pm 0.48^{\mathrm{d}}$ & $2.34 \pm 0.56^{\mathrm{a}}$ & $2.12 \pm 0.55^{\mathrm{b}}$ \\
Principal piece length $(\mu \mathrm{m})$ & $37.81 \pm 2.26^{\mathrm{a}}$ & $37.56 \pm 1.78^{\mathrm{b}}$ & $37.48 \pm 2.05^{\mathrm{b}}$ & $37.84 \pm 2.05^{\mathrm{a}}$ \\
Flagella length $(\mu \mathrm{m})$ & $50.47 \pm 2.06^{\mathrm{b}}$ & $50.42 \pm 1.47^{\mathrm{b}}$ & $50.33 \pm 1.83^{\mathrm{b}}$ & $50.67 \pm 1.64^{\mathrm{a}}$ \\
Sperm length $(\mu \mathrm{m})$ & $59.96 \pm 2.13^{\mathrm{b}}$ & $59.72 \pm 1.63^{\mathrm{c}}$ & $60.28 \pm 1.99^{\mathrm{a}}$ & $60.31 \pm 1.72^{\mathrm{a}}$ \\
\hline
\end{tabular}

Note: Means in the same row with different superscript differ significantly $(\mathrm{P}<0.05)$. EGG= Ettawa Grade Goat, KJG= Kejobong Goat, JWG= Jawarandu Goat, KCG= Kacang Goat.

The results showed that there were differences in sperm morphometry of 4 local breed goat $(\mathrm{P}<0.05)$. The differences were found in any part of the sperm. Sperm length of KCG and JWG goats were $60.31 \pm 1.72$; $60.28 \pm 1.99 \mu \mathrm{m}$, in which this value was longer than EGG and KJG sperm $(59.96 \pm 2.13 ; 59.72 \pm 1.63 \mu \mathrm{m})$. The sperm of JWG goats had the widest head size compared to the other 3 breeds. Goats sperm morphometry was reported that length of sperm head was $7.69 \mu \mathrm{m}$, width of sperm head was $3.80 \mu \mathrm{m}$ and width/length ratio was $0.5 \mu \mathrm{m}$ (Gravance et al., 1995). The result of this study showed that sperm head size of Central Java Goats is larger than before finding. Head width among Central Java goats were 4.85-5.36 $\mu \mathrm{m}$, and head length were 9.30-9.95 $\mu \mathrm{m}$.

The sperm of JWG goats has widest midpiece area $(17.46 \pm 2.72 \mu \mathrm{m})$, the smellers midpiece was found in KJG $(16.43 \pm 2.55 \mu \mathrm{m})$, while longer flagella was obtained in KCG goats $(50.67 \pm 1.64 \mu \mathrm{m})$. The flagella length of the EGG, KJG and JWG was 50.47 $\pm 2.06,50.42 \pm 1.47$, $50.33 \pm 1.83 \mu \mathrm{m}(\mathrm{P}>0.05)$, respectively. This results were consistent with the previous finding which stated that sperm length and sperm width of the sheep, pig and bull were 8.0-10.0 x 4.0-4.5 $\mu \mathrm{m}$ with head thickness head was 0.5-1.5 $\mu \mathrm{m}$ (Garner \& Hafez, 2000). The sperm body was about twice of the length of the sperm. Length of the sperm tails were 35-45 $\mu \mathrm{m}$. Generally length of the sperm was $50-70 \mu \mathrm{m}$. The staining technique used may affect the sperm head length and principal piece length (Arifiantini et al., 2006).

\section{Relationship between Midpiece Area and Principal Piece Length}

There was a significant positive relation between midpiece area and principal piece length at all breeds, although correlation was low $\left(r=0.46 ; r^{2}=0.1316 ; \mathrm{P}<0.05\right.$; $\mathrm{n}=40$ buck (3200 sperm). Significant relationships within breeds, included in EGG $\left(r=0.30 ; r^{2}=0.0909 ; \mathrm{P}<0.05 ; \mathrm{n}=10\right.$ buck), KJG ( $\mathrm{r}=0.43 ; \mathrm{r}^{2}=0.1820 ; \mathrm{P}<0.05 ; \mathrm{n}=10$ buck), KJG $\left(\mathrm{r}=0.42 ; \mathrm{r}^{2}=0.1794 ; \mathrm{P}<0.05 ; \mathrm{n}=10\right.$ buck $)$, JWG $\left(\mathrm{r}=0.33 ; \mathrm{r}^{2}=\right.$ 0.1087; $\mathrm{P}<0.05 ; \mathrm{n}=10$ buck). Relationships between midpiece area and flagella length (include principal piece) 
was also exists in passerine birds (Immler \& Birkhead, 2007). A significant relationship between midpiece area and flagella length was used as a possible indicator of the metabolic regulation of sperm.

Relationships between two sperm components (midpiece area and principal piece length) are important due mitochondrial contain of midpiece which resulting energy for sperm movement. All sperm components (head, midpiece and flagella) in an integrative manner, and each component have a functionally important and contribute to enhance sperm velocity (Gomendio \& Roldan, 2008). Longer flagella without larger midpiece area may impact on sperm longevity, because longer flagella may resulting greater velocity and surely need greater energy. Thus, the sperm velocity and longevity may depend on it components.

\section{Relationship between Sperm Morphometry and Sperm Competition}

There were significant positive relationships between testis mass and sperm length at all of local goat breeds. Although the result showed a significant, however the value of coefficient of determinant was low (Table 2).

Figure 2 shows that there were two major groups sperm category from 4 local goat breeds based on sperm morphometry. The first group consisted of KCG, EGG and KJG, and the second group was JWG. This result was different from categorize group based on morphometrical measurements showing two groups where the first group consisted of KJG, JWG, and EGG and the second group was KCG (Kurnianto et al., 2013). This result indicated that large or longer body size does not always produces the large or longer sperm size.

There were a positive relationships between midpiece area and principal piece length of local goats sperm at all breeds although the value of coefficient of correlation was low. The increasing in sperm swimming velocity was output from length of the flagella and supported by greater energy supply. This will be beneficial in reaching the site of fertilization and give a better sperm penetration to the ovum (Byrne et al., 2003). However, an increasing flagella length without followed by an increasing midpiece may impact on sperm viability due to the sperm midpiece contain of mitochondrial producing sperm energy.

Relative mass of testis was believed to be used for measure the level of sperm competition in several species including mammals (Gage \& Frenckleton, 2003). There were significant positive relationships between sperm length and testis mass (proxy sperm competition) $(\mathrm{P}<0.05)$, although no significant relationship was found in the principal piece flagella length $(\mathrm{P}>0.05)$. The regression analysis showed that coefficient of determinant between sperm morphometry and sperm competition was low $\left(\mathrm{r}^{2}\right)$. It means that there was a dominance of other factors beyond the sperm morphometry in the sperm competition (Table 2).

Although the value of $r^{2}$ was low, there was an evidence of a positive relationship between sperm morphometry and sperm competition. It was consistent with the previous finding, in which there was a close relationship between sperm size and sperm competition level in 226 species of mammals (Tourmente et al., 2011). In contrast, Gage \& Freckleton (2003) found no evidence of

Table 2. Relationships between sperm morphometry and sperm competition in four breeds of local goat

\begin{tabular}{|c|c|c|c|c|c|c|}
\hline \multirow{2}{*}{ Sperm morphometry } & \multirow{2}{*}{ Intercept } & \multicolumn{2}{|c|}{ Slope } & \multirow{2}{*}{$\mathrm{r}^{2}$} & \multirow{2}{*}{$\mathrm{CV}$} & \multirow{2}{*}{$\mathrm{P}$} \\
\hline & & Body mass & Testis mass & & & \\
\hline Head length $(\mu \mathrm{m})$ & 9.563 & -0.0154 & 0.0017 & 0.0552 & 5.97 & $<0.0001$ \\
\hline Head width $(\mu \mathrm{m})$ & 4.971 & -0.0081 & 0.0012 & 0.0404 & 7.72 & $<0.0001$ \\
\hline Midpiece area $(\mu \mathrm{m})$ & 16.154 & -0.1076 & 0.0031 & 0.0089 & 14.85 & $<0.0001$ \\
\hline Midpiece length $(\mu \mathrm{m})$ & 12.94 & 0.0027 & -0.0007 & 0.0018 & 8.69 & 0.0533 \\
\hline Midpiece width $(\mu \mathrm{m})$ & 2.080 & -0.0035 & 0.0005 & 0.0046 & 24.53 & 0.0006 \\
\hline Principal piece length $(\mu \mathrm{m})$ & 37.541 & -0.0011 & 0.0005 & 0.0004 & 5.42 & $0.5608^{\text {ns }}$ \\
\hline Flagella length $(\mu \mathrm{m})$ & 50.481 & 0.0016 & -0.0002 & 0.0001 & 3.50 & $0.8954^{\mathrm{ns}}$ \\
\hline Sperm length $(\mu \mathrm{m})$ & 60.042 & -0.0138 & 0.0015 & 0.0043 & 3.15 & 0.0010 \\
\hline
\end{tabular}

Note: * NS (Non Significant), CV (Coefficient of Variance).

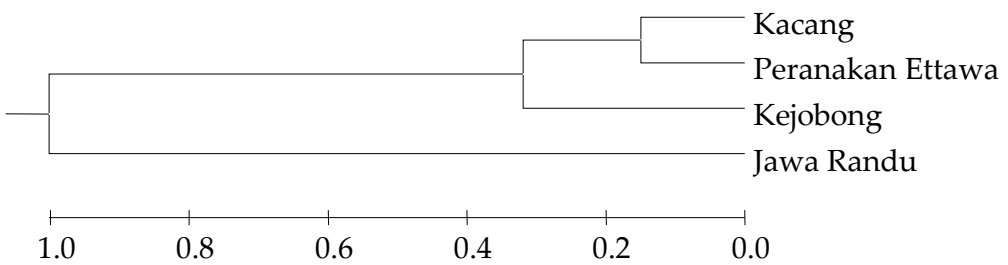

Figure 2. Phylogeny on sperm morphometry 
relationship between sperm length and sperm competition level in 83 species of mammals.

Sperm competition is a matter, which still debated among related researchers, especially in mammals showing differences results. Exploration about research regarding to local goats are still rarely reported in Indonesia. Related studies have been reported in mammals (Anderson et al., 2005; Malo et al., 2005; Tourmente et al., 2011), snake (Tourmente et al., 2009), amphibia (frogs) (Byrne et al., 2003), and sea urchin (Fitzpatrick et al., 2010).

Analysis results within breeds showed that there were significant positive relationships between sperm length and sperm competition level in KJG and KCG $(\mathrm{P}<0.05)$, however there was no significant relationship in EGG and JWG (Table 3). There was no significant relationship between principal piece and sperm competition level in three breeds (EGG, KJG and JWG), how-

Table 3. Relationship between sperm morphometry and sperm competition within breeds

\begin{tabular}{|c|c|c|c|c|c|c|}
\hline \multirow{2}{*}{ Sperm morphometry } & \multirow{2}{*}{ Intercept } & \multicolumn{2}{|c|}{ Slope } & \multirow{2}{*}{$\mathrm{r}^{2}$} & \multirow{2}{*}{$\mathrm{r}$} & \multirow{2}{*}{$P$} \\
\hline & & Body mass & Testis mass & & & \\
\hline \multicolumn{7}{|l|}{ EGG $(n=10)$} \\
\hline Head length $(\mu \mathrm{m})$ & 9.128 & -0.0097 & 0.0018 & 0.026 & 0.16 & $<0.0001$ \\
\hline Head width $(\mu \mathrm{m})$ & 4.758 & -0.0076 & 0.0015 & 0.026 & 0.16 & $<0.0001$ \\
\hline Midpiece area $(\mu \mathrm{m})$ & 15.233 & -0.0373 & 0.0077 & 0.026 & 0.16 & $<0.0001$ \\
\hline Midpiece length $(\mu \mathrm{m})$ & 13.267 & 0.0042 & -0.0017 & 0.013 & 0.11 & 0.0053 \\
\hline Midpiece width $(\mu \mathrm{m})$ & 1.436 & -0.0044 & 0.0018 & 0.061 & 0.25 & $<0.0001$ \\
\hline Principal piece length $(\mu \mathrm{m})$ & 38.455 & 0.0148 & -0.0030 & 0.004 & 0.06 & $0.2218^{\text {ns }}$ \\
\hline Flagella length $(\mu \mathrm{m})$ & 51.723 & 0.0191 & -0.0047 & 0.013 & 0.11 & 0.0065 \\
\hline Sperm length $(\mu \mathrm{m})$ & 60.849 & 0.0094 & -0.0029 & 0.005 & 0.07 & $0.1218^{\text {ns }}$ \\
\hline \multicolumn{7}{|l|}{ KJG (n=10) } \\
\hline Head length $(\mu \mathrm{m})$ & 8.466 & -0.0241 & 0.0050 & 0.189 & 0.44 & $<0.0001$ \\
\hline Head width $(\mu \mathrm{m})$ & 4.404 & -0.0131 & 0.0027 & 0.160 & 0.40 & $<0.0001$ \\
\hline Midpiece area $(\mu \mathrm{m})$ & 15.671 & -0.0742 & 0.0102 & 0.042 & 0.21 & $<0.0001$ \\
\hline Midpiece length $(\mu \mathrm{m})$ & 11.309 & -0.007 & 0.0051 & 0.052 & 0.23 & $<0.0001$ \\
\hline Midpiece width $(\mu \mathrm{m})$ & 2.049 & -0.0059 & 0.0005 & 0.005 & 0.07 & $0.1546^{\mathrm{ns}}$ \\
\hline Principal piece length $(\mu \mathrm{m})$ & 36.69 & 0.0119 & 0.0011 & 0.004 & 0.06 & $0.1883^{\text {ns }}$ \\
\hline Flagella length $(\mu \mathrm{m})$ & 47.997 & 0.0049 & 0.0063 & 0.062 & 0.25 & $<0.0001$ \\
\hline Sperm length $(\mu \mathrm{m})$ & 56.263 & -0.0193 & 0.0113 & 0.129 & 0.36 & $<0.0001$ \\
\hline \multicolumn{7}{|l|}{ KCG (n=10) } \\
\hline Head length $(\mu \mathrm{m})$ & 9.843 & -0.012 & 0.0005 & 0.018 & 0.13 & 0.0007 \\
\hline Head width $(\mu \mathrm{m})$ & 5.295 & -0.0091 & 0.0000 & 0.023 & 0.15 & $<0.0001$ \\
\hline Midpiece area $(\mu \mathrm{m})$ & 15.422 & 0.0235 & 0.0025 & 0.014 & 0.12 & 0.0045 \\
\hline Midpiece length $(\mu \mathrm{m})$ & 12.382 & 0.0157 & 0.0001 & 0.007 & 0.08 & 0.0721 \\
\hline Midpiece width $(\mu \mathrm{m})$ & 1.914 & 0.0024 & 0.0006 & 0.009 & 0.09 & 0.0298 \\
\hline Principal piece length $(\mu \mathrm{m})$ & 36.597 & 0.024 & 0.0023 & 0.017 & 0.13 & 0.0010 \\
\hline Flagella length $(\mu \mathrm{m})$ & 48.979 & 0.0397 & 0.0023 & 0.046 & 0.21 & $<0.0001$ \\
\hline Sperm length $(\mu \mathrm{m})$ & 58.821 & 0.0277 & 0.0028 & 0.036 & 0.19 & $<0.0001$ \\
\hline \multicolumn{7}{|l|}{ JWG (n=10) } \\
\hline Head length $(\mu \mathrm{m})$ & 9.838 & -0.0051 & 0.0008 & 0.011 & 0.11 & 0.0108 \\
\hline Head width $(\mu \mathrm{m})$ & 5.232 & -0.0001 & 0.0003 & 0.002 & 0.05 & $0.4322^{\text {ns }}$ \\
\hline Midpiece area $(\mu \mathrm{m})$ & 16.75 & 0.0415 & -0.0021 & 0.022 & 0.15 & 0.0001 \\
\hline Midpiece length $(\mu \mathrm{m})$ & 13.318 & 0.0199 & -0.0031 & 0.043 & 0.21 & $<0.0001$ \\
\hline Midpiece width $(\mu \mathrm{m})$ & 2.544 & 0.0030 & -0.0008 & 0.007 & 0.09 & 0.0521 \\
\hline Principal piece length $(\mu \mathrm{m})$ & 37.887 & -0.0126 & 0.0001 & 0.004 & 0.06 & $0.2313^{\text {ns }}$ \\
\hline Flagella length $(\mu \mathrm{m})$ & 51.207 & 0.0073 & -0.0030 & 0.008 & 0.09 & 0.0474 \\
\hline Sperm length $(\mu \mathrm{m})$ & 61.043 & 0.0022 & -0.0023 & 0.003 & 0.06 & $0.2731^{\mathrm{ns}}$ \\
\hline
\end{tabular}

Note: NS= non significant, EGG= Ettawa Grade Goat, KJG= Kejobong Goat, JWG= Jawarandu Goat, KCG= Kacang Goat. 
ever there was a significant positive relationship in KCG $(\mathrm{P}<0.05)$. The inconsistent result was found in Passerinde birds (Immler \& Birkhead, 2007).

Sperm size has an important role in sperm competition, while the sperm length is known related to sperm velocity (Tourmente et al., 2011). The high motility was described as sperm swimming velocity. A successful of fertilization is a complex event, one of which is determined by individual of sperm to keep the fertilize ability and arrive in site of fertilization. Longer flagella can produce higher velocity and provides a power boost to early arrives in oviduct, so it can be predicted that longer sperm able to swim faster to reach the site of fertilization (Gomendio \& Roldan, 2008).

Sperm competition is a complex event that occurs in the female reproductive organs. The female reproductive organs may have a stronger impact than sperm morphometry in the sperm competition, this assumption may cause value of $\mathrm{r}^{2}$ was low (Minder et al., 2005; Immler \& Birkhead, 2007).

\section{CONCLUSION}

There are differences in sperm morphometry among 4 breeds of local goats. Sperm morphometry has a significant positive relation to sperm competition level in local goats of Central Java. The next experimental study is needed to demonstrate this finding.

\section{REFERENCES}

Arifiantini, R. I., T. Wresdiyanti, \& E. F. Retnani. 2006. Kaji banding morfometri spermatozoa sapi Bali (Bos sondaicus) menggunakan pewarnaan Williams, Eosin, Eosin Nigrosin dan Formol-Saline. J. Sain Vet. 24:65-70.

Anderson, M. J., J. Nyholt, \& A. F. Dixion. 2005. Sperm competition and the evolution of sperm midpiece volume in mammals. J. Zool. 267: 135-145. http://dx.doi.org/10.1017/ S0952836905007284

Byrne, P. G., L. W. Simmons, \& J. D. Roberts. 2003. Sperm competition and the evolution and the evolution of gamete morphology in frogs. Proc. R. Soc. B 270: 2079-2086. http:// dx.doi.org/10.1098/rspb.2003.2433

Firman, C. R. \& L. W. Simmons. 2009. Sperm midpiece length predicts sperm swimming velocity in house mice. Biol. Lett. 6:513-516. http://dx.doi.org/10.1098/rsbl.2009.1027

Fitzpatrick, J. L., F. Garcia-Gonzalez, \& J. P. Evans. 2010. Linking sperm length and velocity: the importance of intramale variation. Biol. Lett. 6: 797-799. http://dx.doi.org/10.1098/ rsbl.2010.0231

Gage, M. J. G. \& R. P. Frenckleton. 2003. Relative testis size and sperm morphometry across mammals: no evidence for association between sperm competition and sperm length. Proc. R. Soc. B 270:625-635. http://dx.doi.org/10.1098/ rspb.2002.2258

Garner, D. L. \& E. S. E. Hafez. 2000. Spermatozoa and Seminal Plasma. In: B. Hafez \& E. S. E. Hafez (Eds.). Reproduction in Farm Animals. $7^{\text {th }}$ Ed. Lippincot Wiliams \& Wilkins. Philadelphia.
Gomendio, M. \& E. R. S. Roldan. 2008. Implications of diversity in sperm size and function for sperm competition and fertility. Int. J. Dev. Biol. 52: 439-477. http://dx.doi. org/10.1387/ijdb.082595mg

Gravance, C. G., K. M. Lewis, \& P. J. Casey. 1995. Computer automated sperm head morphometry analysis (ASMA) of goat sperm. Theriogenology 44: 989-1002. http://dx.doi. org/10.1016/0093-691X(95)00286-H

Hosken, D. J. \& P. I. Ward. 2001. Experimental evidence for testis size evolution via sperm competition. Ecol. lett. 4:10-13. http://dx.doi.org/10.1046/j.1461-0248.2001.00198.x

ICRU, 1989. Tissue Substitutes in Radiation Dosimetry and Measurement, Report 44 of the Comimission on Radiation Units and Measurements, Bethesda, MD.

Immler, S. \& T. R. Birkhead. 2007. Sperm competition and sperm midpiece size: no consistent pattern in passerine birds. Proc. R. Soc. B. 274:561-568. http://dx.doi.org/10.1098/ rspb.2006.3752

Kurnianto, E., S. Sutopo, E. Purbowati, E. T. Setiatin, D. Samsudewa, \& T. Permatasari. 2013. Multivariate analysis of morphological traits of local goats in central java, Indonesia. Iran. J. Appl. Anim. Sci. 3:361-367.

Lüpold, S., S. Calhim, S. Immler, \& T.R. Birkhead. 2009. Sperm morphology and sperm velocity in passerine birds. Proc. R. Soc. B 276:1175-1181. http://dx.doi.org/10.1098/ rspb.2008.1645

Malo, A. F., J. Garde, A. J. Soler, A. J. Garcia, M. Gomendio, \& E. R. S. Roldan. 2005. Male fertility in natural populations of red deer is determined by sperm velocity and the proportion of normal spermatozoa. Biol. Reprod. 72: 822-829. http://dx.doi.org/10.1095/biolreprod.104.036368

Malo, A. F., M. Giomendio, J. Garde, B. Lang-Lenton, A. J. Soler, \& E. R. S. Roldan. 2006. Sperm design and sperm function. Biol. Lett. 2:246-249. http://dx.doi.org/10.1098/ rsbl.2006.0449

Marco-Jiménez, F., M. P. Viudes-de-Castro, S. Balasch, E. Mocé, M. A. Silvestre, E.A. Gomez, \& J.S. Vicente. 2006. Morphometric changes in goat sperm heads induced by cryopreservation. Cryobiology 52: 295-304. http://dx.doi. org/10.1016/j.cryobiol.2006.01.002

Minder, A. M., D. J. Hosken, \& P. I. Ward. 2005. Co-evolution of male and female reproductive characters across the Scatophagidae (Diptera). J. Evol. Biol. 18:60-69. http://dx.doi. org/10.1111/j.1420-9101.2004.00799.x

Parker, G. A. \& T. Pizzari. 2010. Sperm competition and ejaculate economics. Biol. Rev. 85: 897-934.

SAS Institute. 2004. SAS ${ }^{\circledR} / S T A T$ Software, Release 9.11. SAS Institute, Inc., Cary, North Carolina.

Sears, F. W., \& M. W. Zemansky. 1994. Fisika untuk Universitas 1. Bina Cipta, Jakarta.

Tamura, K., D. Peterson, N. Peterson, G. Stecher, M. Nei, \& S. Kumar. 2011. MEGA 5: Molecular evolutionary genetics analysis using maximum likelihood, evolutionary distance, and maximum Parsimony methods. Mol. Biol. Evol. 28:2731- 2739. http://dx.doi.org/10.1093/molbev/msr121

Tourmente, M., M. Gomendio, E. R. S. Roldan., L. Giojalas, \& M. Chiaraviglio. 2009. Sperm competition and reproductive mode influence sperm dimensions and structure among snakes. Evolution. 63: 2513-2524. http://dx.doi.org/10.1111/ j.1558-5646.2009.00739.x

Tourmente, M., M. Gomendio, \& E. R. S. Roldan. 2011. Sperm competition and the evolution of sperm design in mammals. J. Evol. Biol. 11:12 1471-2148. 